\title{
The Weight of Secrets: Hidden Mirrors of Identity in Aki Shimazaki's Pentalogy
}

Peter SCHULMAN

In Tsubaki, the first of Aki Shimazaki's series of five novels, a Rashomon'-like pentalogy in which the same characters try to unravel the personal traumas of their lives right before the atom bomb hits Nagasaki, the city that they have just moved to, one of the main characters, Yukio, cries out: "Ce n'est pas le temps de chercher la vérité, c'est l'unité qui compte" (Tsubaki 53). In that instance, he was defending a young Korean unjustly accused of theft. Could the same be said for the rest of Shimazaki's novels? Indeed, in Tsubame, for example, the narrator, a Korean immigrant living in suburban Tokyo must hide her identity during the war to escape persecution and murder, has her name changed from the Korean Yonhi to the more Japanese-sounding Mariko, but continues her spiritual camouflage well after Japan's defeat in World War II to the point where her own family believes she is in fact Japanese. "Je ne parle à personne de mon origine," she explains, "Mon fils croit, comme autrefois mon mari, que ma mère et mon oncle sont morts pendant le tremblement de terre, en 1923. La défaite du Japon et l'indépendance de la Corée n'ont rien changé à l'attitude des Japonais contre les Coréens au Japon" (Tsubame 61). Shimazaki's main character is a crypto-Korean living in war-torn then post-war Japan while Shimazaki herself is a Japanese woman living in Canada but writing in French. Shimazaki's enigmatic Japanese titles to her books are indicative of her own idiosyncratic mise-en-abyme nar- 
ratives in which there can be several layers of identity hidden within the frames of language (French for Shimazaki, Japanese for her Korean-born characters living in Japan, and finally silence for the adulterous narrator of Hotaru). How does French function as a unifying mirror for these many layers of identity that are hidden throughout her novels? Could an Asian-Québecois public persona in a city as linguistically polarized as Montreal be a fitting depository for the secrets Shimazaki wishes to keep from her own Japanese past? Shimazaki's quasi-obsessive preoccupation with a single traumatic event viewed from many angles, and her elegant attempts to camouflage the secrets her characters with enigmas taunt her readers towards such questions. Indeed, her titles are all delicate, elegant origami-like metaphors for her characters' deep inner feelings (Tsubame means "Swallow", a metaphor for the flight the main character wishes to embark upon from her painful childhood; Hotaru is the "firefly" the narrator wishes to be at night when she is seduced by a selfish married man; and Hamaguri is a Japanese clam representing the shells the narrator and her mother try to put together to connect with as well as to shelter each other from the mother's wartime horror). "Je ne pourrai jamais avouer l'histoire de mon origine à mon fils et à sa famille," the narrator of Tsubame confesses, "Je ne veux absolument pas que notre vie en soit perturbée" (Tsubame 61). In what she chooses to reveal to her readers, however, Shimazaki pirouettes with language as well as collective and personal trauma to fulfill a type of unity within her writing: a unity similar to the string of shells the characters symbolically create in Hamaguri to protect themselves and others from both truths and lies.

"Le français m'a apporté la clarté et la précision," Shimazaki explains in an interview with François Dargent in Le Figaro. "Ce qui est à l'opposé de la mentalité japonaise" (Figaro 2).

Indeed, if Mariko's mother urges her daughter to never take freedom for granted, "rien n'est plus précieux que a liberté. N'oublie jamais ça, Yonhi" (Tsubame 20), French may have given Shimazaki a freedom of creative expression that enables her to see her country of origin with more clarity and direction that she might have had she written her novels, which are all set in Japan, in Japanese. Shimazaki, who now teaches Japanese and translates in Montreal, has been writing in French for the past fifteen years after having lived in Vancouver and Toronto briefly. It took her just under six years to complete each of the five novels: Tsubaki, le poids des secrets (1999); Hamaguri (2000); Tsubame (2001); Wasurenagusa (2003); Hotaru (2004). She has in fact followed a long line of great authors who have adopted French as their literary language of choice. If famous, now 
canonic writers such as Ionesco, Beckett, and Kundera all wrote their masterpieces in French rather than in their native tongues, Shimazaki now joins a whole new generation of successful writers who have done the same today. Recently, the Goncourt prize had been awarded to Tahar Ben Jelloun, Amin Maalouf, André Makine, and in the last two years, the American Jonathan Littell and the Afghan Atic Rahimi who broke from his native Persian in order to find the right voice for Singué Sabour. "Au depart, je ne me posais même pas la question, je n'y pensais pas," he reminisces to Dargent. "Quand je suis retourné dans mon pays en 2002, j'ai retrouvé ma culture...et l'envie d'écrire en français. Singué Sabour, pierre de patience est sorti directement en français. En fait, il m'était difficile - je ne sais pourquoi- d'aborder ces sujets importants, tabous, dans ma langue maternelle. La langue française m'a donné la possibilité de m'exprimer avec une certain liberté" (Figaro 2). For Shimazaki, the moment she knew she wanted to write in French came after she read the work of Hungarian author Agota Kristof who also chose to write in French. It was after having read his novel, Le grand cahier, that Shimazaki decided to make French her adopted literary language: "J'ai été fascinée par son style très simple et son histoire si profonde. A cette époque, $j$ 'avais déjà des idées pour mon roman Tsubaki. Alors, j'ai decidé de l'écrire directement en français. Il m'a fallu trois an pour l'achever" (Figaro 3).

Although one can read the novels of the pentalogy in any order as each story can be approached on its own merits, it is easy to get tangled in the narratives as each one represents a particularly intense search for individual identity, resolution or absolution that is nonetheless interwoven into an original relationship matrix set off by Mariko, the mother and grandmother of several narrator/protagonists and Mr. Horibe, a lecherous married man she has an affair with. Moreover, the pentalogy is also highly engaged in the violent upheaval within the historical narratives of war-torn and post-atomic Japan. The first novel in the series, Tsubame, for example, begins with the death of Yukiko, who reveals the secrets of her tormented life in Nagasaki during World War II through a long, confessional letter; Hamaguri is written from the point of view of Yukio, Mariko's son, who slowly reveals his poetic friendship/love for Yukiko when they were both children and each of their parents would take them to the same park. There they made a loyalty oath to each other which they inscribed in a clam shell. Once they become adolescents, they find themselves in Nagasaki without recognizing each other. During the last hour of her life, Yukio's mother retrieves the clam shell for her son, and opens a floodgate of memory during which he realizes he is Horibe's illegitimate son, and Yukiko is his 
half-sister. In Tsubame, Shimazaki firmly places her narrative within the horrors of the catastrophic 1923 Tokyo earthquake which caused 140,000 deaths. It is during that brutal chaos that Mariko must take on a Japanese identity as the Japanese were unleashing a murderous racist onslaught towards Koreans living in their country. Towards the end of her life, as a widower, mother, and grandmother of three, she learns the truth about her identity and the catholic priest who protected her after the earthquake and saved her life. In Wasurenagusa, the narrative voice shifts to Kenji Takakashi who married Mariko and adopted her son Yukio. After a failed first marriage, and after learning that he is in fact sterile, he falls in love with Mariko against the wishes of his parents who frown on her situation (a single parent of an illegitimate child) and disown him. His only attachment is to Sono, his nurse growing up. Forty-six years later, retired and frail, he decides to seek Sono out. When he tracks down her gravesite, he too discovers his own secret identity and learns of how the vicious Horibe had him transferred to Japanese-occupied Manchuria during the war to keep him away from his mistress Mariko whom he continued to desire. When the Russians overrun Manchuria after Japan's collapse, he is sent to a labor camp. He also finds out that he too was adopted and that Sono was his real mother. In Hotaru, the last novel in the series, Shimazaki ends with the event that spawned the rest of the books, Mariko's early relationship with the married Horibe who selfishly tries to control her as his mistress. The last novel is told from Mariko's granddaughter's point of view as she learns of her grandmother's past. Little by little, in a manner similar to the reader's experience with the pentalogy, Mariko confides in her granddaughter and reveals the ultimate secret of how Yukiko poisoned her own father with cyanide right before the atomic bomb hits Nagasaki when she found out how he had treated Mariko. When Kenji Takahashi remembers hearing someone ask him once "Vous êtes d'origine douteuse, n'est-ce pas?" (Wasurenagusa 84), he could very well be hearing an echo of the subconscious doubt that haunts each generation of characters from grandmother to grandchild through the five novels.

While the series of books Shimazaki writes unify all the characters within a similar trauma, the horrors of World War II, each of the protagonists suffers personal trauma as a result of one fundamental adulterous relationship, and the fruit of that relationship, an illegitimate boy who must continuously question his own roots. His half sister, who shares the same father as the boy, Mr. Horibe, is also linked to the series of anguished relationships. As Paul Ricoeur has suggested in regards to collective memory and its parallel phenomenon, collective oblivion, personal trauma is 
often engulfed by collective ones as well: "Ce n'est donc pas avec la seule hypothèse de la polarité entre mémoire individuelle et mémoire collective qu'il faut entrer dans le champ d'histoire," Ricoeur writes, "mais avec elle d'une triple attribution de la mémoire: à soi, aux proches, aux autres" (Ricoeur 163). As such, in Tsubame, we learn that much of Shimazaki's ensuing pentalogy rests upon several layers of hidden identities and events that only a single document, a diary written in Korean by the narrator's grandmother, is able to unravel and reveal. In addition to the horrors of illegitimacy, the narrator, Mariko, is also shrouded in the mystery of a collective past: the plight of Koreans living in Japan in the early twenties (and even today). Known as Zainichi, Korean-Japanese have suffered untold racism and feelings of unworthiness that Melissa L. Wender has described in terms of "lamentation as history" in her book of that title and what the famous Japanese critic Eto Jun has labeled "maturity and loss" in his analysis of Zainitchi literature. Throughout the $20^{\text {th }}$-century, regarding that work, Wender remarks, "although the subtitle to Eto's book is 'The Decline of the Mother,' the work in fact deals almost exclusively with the loss of authority of the father in postwar Japan" (Wender 216n14). Within this context, one can also read Shimazaki's pentalogy in terms of the loss of paternal authority in the sense that Yukio never knows who his biological father is (even though he lurks very close by in order to extend his affair with Mariko). Moreover, we learn that Yukio's stepfather, Mr. Takashi, is in fact sterile in book five, Wasurenagusa.

As Seiju Takeda explains regarding the "Zainitchi condition," the "second generation of Zainichi [...] at some point must abandon an ideological desire for 'society' and land themselves in the order of personal life. Then the impulse to appear that abandonment through the narratives of 'the family', 'the history,' 'ethnicity,' 'nation,' is impressed upon them. What we must note is that the desire for 'reconciliation' with the 'father' or 'history' at this time in reality appears as a conflicting discourse with those "various ideologies"' (Wender 63). Just as Zainitchi were forced to be fingerprinted in Japan, and often had to change their names to Japanese ones, Shimazaki's characters bury their external traces of identity and leave only the metaphoric fingerprints of who they really are and what they want to be in the titles of each novel which, to Francophone readers, are nonetheless codified and secretive as they are all Japanese words. Similarly, each book is filled with so many Japanese expressions that they have a lexicon of terms at the end in order to give the reader an "Ariadne's clew" or a trace with which to navigate the daedalus Shimazaki's work progressively becomes. In this way, the five books represent five facets 
of a fragmented identity that is initially sparked by a historical trauma, the monstrous 1923 earthquake which Shimazaki represents as a type of holocaust as poorer neighborhoods are wiped out by flames and Japanese troops begin to randomly kill all Koreans as scapegoats and enemies of the people. As the narrator digs deeply into her childhood memories that had been thoroughly repressed, she remembers the smoldering houses around her and then the sudden spasm of violence against her people- just as they are in the most vulnerable and weakest of positions: "Soudain on entend des cris. Puis plusieurs hommes paraissent devant la foule. Ils ont un sabre, une lance de bambou, une gaffe. Je ne comprends pas ce qui se passe" (Tsubame 28). Through the child's eye filtered by memory and its companion, oblivion, the nonsensical brutality becomes clearer and clearer in her mind: "L'un des hommes dit: 'Arrêtez tous les Coréeens! Ils sont dangereux. Ils tentent de jeter du poison dans les puits/ La foule s'agite. Un autre homme lance: - Les Coréens mettent le feu! Ils volent à mains armée! Ils violent les femmes! Quoi? Je regarde ma mère. La bouche cousue, elle me fait signe de ne pas parler. Son visage est tout crispé" " (29-30).

If Wenders describes post-war Zainichi literature as "uncircumcised ethnicity" in reference to Moses's "uncircumcised lip" in the Bible (often interpreted as a stutter), the silence that the narrator must endure out of terror is only diffused years later through writing and metaphoric invention throughout the pentalogy. So great is the terror within the memory:

Le troisième homme dit: - capturez tous les Coréens sans exceptions! Les autres poussent des cris en agitant les armes. La foule panique. Je ne bouge pas. Tout mon corps frémit de peur. La femme au petit garçon nous regarde, ma mère et moi. Les hommes armées circulent entre les gens. L'un deux s'arrête devant ma mère, l'air soupçonneux. A un moment où il ouvre la bouche, la femme crie: "-Madame Kanzawa! Je ne savais pas que vous étiez ici." (30)

At the last minute, she and her mother are saved by a lie, a change of identity, and a change in family name. Similar to the Jewish Sally Perel, who in his World War II autobiography Europa, Europa reveals that, in parallel circumstances in Russia, as the Germans invade the USSR and interrogate him, he saves his own life by pretending to be Aryan and goes on to be assimilated by the Wermacht as a young Nazi soldier at the front. ${ }^{2}$ When, at the end of the episode in which they are saved, Mariko's mother declares, with tears in her eyes: "Il faut partir maintenant," she 
is also alluding to the spiritual departure that both mother, daughter and future offspring will have to undertake, not away from Japan towards the motherland, but far away from their authentic identities that must be buried within them as a security field against death in the immediate and, later, against racism and self-exile. As Lucie Lequin understands it, the trauma experienced by Shimazaki's characters is an especially collective one for Koreans in Japan as a result of the frenzied thanatos released after the 1923 earthquake. The Zainitchi found themselves trapped in a situation with no exit:

La différence poussée à son paroxysme est, dans le pire des cas, pour les uns cause de mort, pour les autres, cause de peur, de sentiment d'étrangeté et de mensonge puis cette différence, déterminée par la norme, tue. Cette "rumination haineuse" [selon Daniel Sibony] collective se fait conviction; elle est normale. Devant une telle haine maladive, les étrangers ou plutôt ceux qui sont étiquetés étrangers doivent donc se protéger, fuir parfois, ou encore se donner une identité qui n'est pas la leur. (Lequin 41)

In Tsubame, however, what identity must the narrator take on, in addition to a simply Japanese one? Indeed, all traces of her Korean past are erased, including heroic images of her activist journalist father who disappeared before she was born, and her uncle who fled repression in Korea only to find more horrific repression in Japan where he too will vanish after the earthquake. ${ }^{3}$ Moreover, as she explains, in addition to memory, she also loses the language of memory, her mother tongue:

Dix ans avaient passé depuis le tremblement de terre. Pendant cette période, je n'avais lu, ni entendu, ni écrit ma langue maternelle. Je n'étais plus capable de lire le Coréen, surtout du [...] journal [de ma mère] qui avait été écrit sous la forme cursive, utilisant beaucoup de caractères du hanmun (ideogrammes chinois). Je n'ai osé montrer le journal à personne pour en connaître le contenu. Depuis, je ne sais pas combien de fois j'ai été tenté de le brûler. Néanmoins, j'ai manqué le courage pour le faire. (Tsubame 60)

Taken under the wing of the European catholic priest who gives her shelter and takes care of other refugees and orphans, she admits to having forgotten all about her mother's diary: "La veille de notre départ, le prêtre $m$ 'a rendu le journal de ma mère que j'avais complètement oublié". $(60)$. Forgetfulness becomes not only a means for continuing to survive 
in war-torn and xenophobic Japan, but a necessity after the war as well. As Lequin explains, with forgetfulness comes life and new strengths with which to confront the past:

Shimazaki [...] fait place à la vie. Même si nombre de ses personnages et de leurs émotions trop longtemps retenues, Shimazaki tente de débusquer derrière les apparences, les blessures identitaires [...] Le travail de la mémoire se place au coeur de son récit, une mémoire singulière, intime, souvent encore voilée malgré une révélation partagée; cependant, contrairement aux derniers personnages de [Ying]Chen qui fuient le réel, les personnages de Shimazaki sont toujours fortement, de plein pied dans le contexte sociopolitique du Japon. (Francographies 108)

Years later, when the narrator joins a crowd as workers begin to unearth a mass grave of Koreans who died in the 1923 massacres, Shimazaki points to the collective memorialization of her trauma as she suddenly yearns and thinks of her mother's bones which might be buried there along with the other anonymous bodies:

J'écarquille les yeux. Je vois, sur la berge, une gigantesque fosse. On pourrait y mettre une maison entière [...] Autour de la fosse se tient un autre groupe de spectateurs. Au fond, plusieurs hommes grattent la terre des parois avec une pelle. Chaque fois que l'un d'entre eux découvre un objet, les gens en haut demandent en se penchant: "qu'est-ce que c'est? Peut être un os!"/Non - sans doute une pièce de verre. "Un os? De qui? De ma mère. De mon oncle..." (79)

The dig becomes a metaphor for her own impromptu digging through her memory and identity issues. It is as though Shimazaki were making a word play on fosse and fausse ("ditch" and "false" in French) in the sense that her true self and origins are being unearthed while her false-Japanese self watches in horror. As she observes a priest who looks down to the dig with a stern expression his face, she can't help noticing his racial characteristics:

Je regarde le visage du père. Les mains croisées, il observe sérieusement l'opération en contrebas. Ses paupières mongoles me rappellent les yeux de mon oncle. Je me demande un moment s'il est d'origine coréenne et s'il cache son identité à ses enfants parce qu'il est devenu japonais.... (79)

Her identification with the priest, "père," is, of course, within Wender's typology, a quest for the missing father that haunts all of 
Shimazaki's characters such as Mariko's son, Yukio, Mariko herself who is protected by the spiritual European father, but exploited by the lecherous adulterer Horibe who refuses to be his son's father by not marrying her; and the missing paternal authority of either the Korean or even the Japanese Fatherland which crumbles as Japan loses the war. When she overhears the priest discuss the various atrocities the Japanese committed after the earthquake, she cannot help becoming increasingly absorbed in the collective narrative of her past and her people: "Il y avait des centaines de cadavres laissés aux champs le cou coupé, le bras tordu, la tête fendue. Même celui d'une femme enceinte, le ventre ouvert, l'enfant visible. C'était une atrocité" (88). As she must decide whether to flee or stay and bury herself even more in stories and memories, she nearly faints, and longs so much for her mother and her maternal roots that she screams to herself hysterically, as the flowers she sees in some girls arms triggers an involuntary reaction: "En un instant je me dis: Maman! Je suis au bout des larmes. Mes pieds tremblent. La femme commence à fredonner la mélodie d'Ariran [la chanson de la Patrie]. Mes larmes tombent. 'Elle est là! Elle est revenue me chercher après cinquante neuf ans d'absence! Le bleu des campanoles brille sur la manche du chogori blanc"(81).

The discovery of buried corpses within Mariko come to the surface of the text just like the many hidden narratives that are interwoven throughout the five books, yet the unearthing of the ultimate secret about the mother's true identity is at the crux of all the different other strands of secrets that Shimazaki writes about. "Il y a des choses qu'on ne peut dire aux autres...", the mother of the narrator of Hotaru whispers at the end of the novel, "Garde cette histoire pour toi, s'il te plait" (129). Fortunately, not only does Shimazaki share the series of secrets with her readers, she also presents them through many facets, many layers, and many aesthetically pleasing "coatings" like the exotic and delicate creatures, flowers and objects that make up the title of each book. The return of the mother through the dig is thus a reconciliation of the different ghosts that haunt the five books that find a type of resolution through the decoding of the very concrete and definitive diary written in Korean, which serves as both a clandestine, and ultimately clarifying document. It is, in this way, similar to the recent instillation by Chantal Akerman, "Walking next to your laces in an empty refrigerator" ["Marcher à coté de ses lacets dans un frigidaire vide"] (2004, Marian Goodman Gallery, NY). As in Shimazaki's pentalogy, the central point of Akerman's instillation revolves around a journal written by her grandmother when she was a teenager in Poland. In the darkened room, texts written by the artist herself, are mixed with selected words from the 
grandmother's journal, and stream across the walls of a room-size spiral structure. As the program describes it: "Made of white, diaphanous material, the spiraling walls call to mind the properties of a screen or scrim, a skin, or even a bandage" (1). In Shimazaki's work, literary words and metaphors also serve as bandages and screens for unspoken tragedies. As Akerman states it, in terms that are parallel to Shimazaki's, "It started off with the journal, my grandmother's journal. The only thing we have left, my mother always says. Often I mull it over in my mind and I work with the notion of lacking, of nothingness [...]. Here, I worked with what we had left. Not much, yet an entire world" (Akerman 1).

While little is known about Shimazaki's own life (as she is very discrete) a part from the fact that she moved to Canada when was in her early forties, it is clear from her writings that she is nonetheless emotionally wedded to the untold stories and quiet sufferings within a Japan that is not always featured in History books (especially those printed in Japan). By confronting the plight of the Zainitchi, for example, or by examining the predicament of the Japanese who were left behind in Manchuria and sent to Soviet labor camps, or even by understanding the inner lives and dramas of ordinary citizens of Nagasaki before and after the atomic bomb hits their city, Shimazaki delves sensitively into the carefully hidden secrets of modern Japan itself. Writing from the origami-like "wrapping" that the French language and a Francophone readership can provide far from her native soil, Shimazaki can write with a sense of relative freedom from the controversies and debates fought by a Japanese public not eager to confront a slice of the past they would rather ignore. With the recent political tempests surrounding such issues as whether conservative Japanese politicians should be able to visit Yasukuni the national shrine where some war criminals are buried, or China bringing up the savagery of the Japanese army in Nanking, or even the now unearthed trauma of the Korean "comfort women" who were forced into Japanese army-run brothels, it would be understandable for Shimazaki to want to carve out a literary oasis for herself far from the possibly oppressive judgments of Japanese public opinion.

In her first novel after the pentalogy, Mitsuba, ("Clover"), Shimazaki does in fact confront the stifling realities of contemporary corporate life in Japan as she deconstructs an affair between a young "salary man," Takashi Aoki, and a secretary, Yûko, who wants to move to Montreal. Although he knows he wants to choose a life abroad with his "soul mate," he is nonetheless trapped by Goshima, the import-export company he works for. In keeping with similar themes in Shimazaki's work, the young man 
must learn to negotiate both his family's past we well as the weight of Japanese tradition. As his mother describes it when he tells her that he might be transferred to either Montreal or Paris:

- Tu t'amuses à travailler, ce n'est pas comme ton père.

Les temps ont changé.

Je me tais. Je me sens lourd en pensant à lui qui a été

chassé du Japon come je suis en train de l'être. Ma mère me regarde: [...]

- Paris ou Montréal, cela m'est égal. Les deux sont loin du Japon.

While the pentalogy focused mostly on the inner and outer struggles associated with the war and its aftermath, in Mitsuba, Shimazaki sheds light on the heaviness of contemporary life as well as the appealing aspect of an alternative land and society: francophone and bi-lingual Montreal. At one point, Yûko recounts the liberating sensation she feels in Quebec which she views as a parallel but ultimately freer universe compared to Kobe, the Japanese city she loves the most: "Elle avait gravi une pente qui menait au belvédère du Mont-Royal. 'C'est Kobe!' s'était-elle écriée. Au loin, elle avait aperçu le fleuve Saint-Laurent semblable à la mer intérieure de Seto. Devant le mont s'étendait la ville de Montréal semblable à celle de Kobe [...] De nouveau, elle avait eu l'illusion d'être chez elle" (Mitsuba 70).

Throughout the novel, the fantasy of escape that Montreal provided for the young salary man had been merged with his passionate love for Yûko whose seemingly courageous leap of faith away from the company and the security it provided could in fact have been an illusion as well. Similarly, Shimazaki's economical and poetic prose (author/artist Sienna Powers has in fact referred to Tsubaki as "Haiku in prose" in her review of that book), interspersed with numerous Japanese words also creates the "illusion" of having been written in Japanese. Yet it is also emblematic of a burgeoning Asian-Canadian literature that is spearheaded by Canada's surging Asian community. Writers such as the Chinese-born Ying Chen, or Korean-Canadian Ook Chung have also endeavored to come to terms with the tension between their respective "homelands" and new communities and mores. Yet, when in Mitsuba, Aoki learns that Yûko has not gone off to Montreal but has married an executive in her company instead, he suddenly gets the final burst he needed to break from his personal chains of tradition that had been holding him back. As he leaves his office for the last time, he tucks his badge in his pocket, as an act of defiance, on 
the one hand, and as a type of identity rebirth on the other: "Des piétons me jettent un coup d'oeil. Certains d'entre eux remarquent le badge de la companie Goshima attaché sur le revers de ma veste. Ils me regardent avec respect et envie. Je me retourne pour voir l'immeuble Goshima. Eclairées par le soleil, les vitres brillent. J'enlève le badge et le mets dans la poche intérieure de ma veste" (140). Just as Aoki can place his Japanese corporate identity in his inside pocket near his heart before undertaking a bold adventure, Shimazaki, through her concise yet mystery-laden writings, is also able to translate deep cultural rumblings into a unique art form.

When, at the end of Tsubame, Shimazaki's last image is of a little boy, "[L']enfant tourne la tête vers moi. C'est Yukio. Il agite sa main: 'Maman! Maman!'”, she seems to be passionately affirming that, despite the absence of many layers of fathers, the maternal world is ultimately the one she returns to and remains the only terra firma she can ever know.

\section{Notes}

1. Rashomon (Akira Kurosawa, dir, 1950).

2. Shlomo Perel, Europa, Europa. Traduit de l'hebreu par Lysette Hassine-Mamane. Paris: Ramsay, 1990.

3. Indeed, Sally Perel experiences a similarly shocking identity crisis in Europa, Europa when he realizes that he has suddenly been transformed into a German soldier: "Salomon, devenu Yop le soldat victorieux, et à present Josef de la Jeunesse hitlérienne, avait trouvé un camouflage idéal et y vivait en toute sécurité. Mais jusqu'à quand? Etait-il possible de vivre ainsi indéfiniment, avec une identité d'emprunt, sans papiers d'identité et avec une circoncision alors meme que ce régime veillait, jusqu'à la démence, à empêcher toute infiltration d'étranger au sein du people sur lequel il régnait de façon totalitaire?" (91)

\section{Works Cited}

Ackerman, Chantal. "Walking next to your laces in an empty refrigerator" ["Marcher à côté de ses lacets dans un frigidaire vide"] (2004, Exhibit presented at the Marian Goodman Gallery, New York City). Dargent, Françoise. "Le français, langue d'accueil de tous les écrivains du monde." Le Figaro. Livres. 01/08/09. www.lefigaro.fr/ livres/2009/01/08 pp. 1-4.

Jun, Eto. Maturity and Loss: The Decline of the Mother (Seijuku to soshitusu: 'haha' no hokai).(Tokyo: Kawade Shobo, 1967). 
Lequin, Lucie. "De la mémoire vive au dire atténué," Voix et Images. Volume 31, Issue 1 [91], 2005, pp. 89-99.

. "Aki Shimazaki et le plaidoyer de la vérité," Dalhousie French Studies, Volume 64, 2003, pp. 39-46.

. "L'Imaginaire des femmes dans l'écriture québecoise actuelle," Francographies, Numéro Spécial, 100ème anniversaire, Colloque 2004, Volume 1, pp. 101-110.

Perel, Shlomo. Europa, Europa. Traduit de l'hebreu par Lysette HassineMamane. Paris: Ramsay, 1990.

Powers, Sienna. "Haiku in Prose." Book review of Tsubaki by Aki Shimazaki translated by Fred A. Reed. Published by Talonbooks in January Magazine, July 2000. (www.januarymagazine.com/fiction/ tsubaki) pp 1-3.

Ricoeur, Paul. La mémoire, l'histoire, l'oubli. (Paris: Seuil, 2000) [Memory, History, Forgetting].

Shimazaki, Aki. Hamaguri. Montreal: Leméac/Arles: Actes Sud, 2000.

. Hotaru: Montreal: Leméac/Arles: Actes Sud, 2004. . Mitsuba: Montreal: Leméac/Arles: Actes Sud, 2006. . Tsubaki. Montreal: Leméac/Arles: Actes Sud, 1999. . Tsubame.Montreal: Leméac/Arles: Actes Sud, 1999. . Wasurenagusa. Montreal: Lémeac/Arles: Actes Sud, 2003.

Sidony, Daniel. Jouissances du dire. Paris: Grasset, 1985.

Takeda, Seiju. " 'Zainichi' to iu konkyo' in "Zainichi" as Foundation, pp. 299-304. (Tokyo: Chikuma Shobo, 1995).

Wenders, Melissa L. Lamentation as History: Narratives by Koreans in Japan, 1965-2000. Stanford, Calif: Stanford University Press, 2005). 
